\title{
Scientific production in pharmaceutical care: comparison between Brazil, USA and Spain
}

\author{
Tadeu Uggere de Andrade1, 2, *, Jaqueliny Louback da Cunha Barbosa ${ }^{1}$, Lívia Lopes Moura \\ Laignier ${ }^{1}$, Elizangela Faustino da Mata ${ }^{1}$, Karla Oliveira dos Santos Cassaro ${ }^{1}$, Dominik Lenz ${ }^{1}$, \\ Karla Nivea Sampaio ${ }^{2}$, Giovanna Assis Pereira Boëchat ${ }^{1}$, Denise Coutinho Endringer ${ }^{1}$ \\ ${ }^{1}$ Department of Pharmacy, University of Vila Velha, Espirito Santo, Brasil, ${ }^{2}$ Department of Pharmaceutical Sciences, \\ Federal University of Espirito Santo, Brazil
}

\begin{abstract}
The aim of this study was to estimate the evolution of the field of Pharmaceutical Care (PC) by measuring the quality and quantity of the scientific production on the topic of PC in Brazil compared to two pioneering countries in the field, the United States of America (USA) and Spain. The databases Web of Science, Scopus, Medline, Lilacs and SciELO were used as sources for the literature search. Pharmaceutical Care, or the appropriate translations, was used as the search term for the literature search, which was limited to articles published between 1990 and 2009. A score of quality (SQ) was calculated using variables such as impact factor and the frequency of the citations. We included 3265 articles published in 544 journals. We found that there was a steady increase in scientific production since 1990 and that the USA had a higher quality of scientific production than Spain, whereas the Spain produced the highest quantity of articles. In comparison, the Brazilian production of scientific publications on PC is low in terms of both quality and quantity but has increased steadily since 2002. Nevertheless, Brazil has not yet reached the level of the USA or Spain. In conclusion, Brazil's scientific production has evolved over the second decade studied in this work, with particularly high levels of production in the last five years. However, an increase in the quantity and quality of the publications should be encouraged.
\end{abstract}

Uniterms: Pharmaceutical care/scientific production. Brazil/pharmaceutical care/scientific production. Spain/pharmaceutical care/scientific production. United States of America/pharmaceutical care/scientific production.

O objetivo deste estudo foi estimar a evolução da área de atenção farmacêutica (AF) através da medição da qualidade e quantidade da produção científica na área de AF no Brasil, comparando-a com os países pioneiros no ramo: Estados Unidos da América (EUA) e Espanha. Os bancos de dados Web of Science, Scopus, Medline, Lilacs e SciELO foram usados como fontes para a pesquisa. AF ou as respectivas traduções foram usadas como descritor para a pesquisa bibliográfica sendo incluídos artigos publicados no período de 1990 a 2009. A pontuação da qualidade (PQ) foi calculada, utilizando variáveis como fator de impacto e frequência das citações. Foram cincluídos 3.265 artigos publicados em 544 revistas. Verificou-se um aumento constante na produção científica desde 1990 sendo que os EUA possuíam maior qualidade, enquanto a maior quantidade de artigos foi produzida na Espanha. Em comparação, a produção brasileira na AF é baixa em qualidade e quantidade, mas tem aumentado desde 2002. Apesar disso, o Brasil ainda não atingiu o nível dos EUA ou Espanha. Em conclusão, o Brasil apresentou expressiva evolução na última década com maior desenvolvimento nos últimos cinco anos. Entretanto, melhoria na quanitdade e qualidade das publicações deve ser incentivada.

Unitermos: Atenção Farmacêutica/produção científica. Brasil/atenção farmacêutica/produção científica. Espanha/atenção farmacêutica/produção científica. Estados Unidos da América/atenção farmacêutica/ produção científica.

"Correspondence: T. U. Andrade. Departamento de Farmácia, Universidade de Vila Velha. Rua Comissário José Dantas de Melo, 21, 29102-770 - Boa Vista - Vila Velha - ES, Brasil. E-mail: tadeu.andrade@uvv.br 


\section{INTRODUCTION}

Internationally, discussions on the roles and functions assigned to the pharmacist have undergone significant transformations and have intensified during the last decades of the twentieth century, especially in the United States and Europe (Olatunde et al., 2009; Hudgens et al., 2010). These changes have also influenced Latin America and led to a strengthening of the relationship between the pharmacist and the patient (Hepler, Grainger-Rousseau, 1995; Faus-Dáder, Martínez, 1999; Martínez, 1999; Penna, 1990; OPAS, 2004).

In Brazil, Pharmaceutical Care (PC) is also becoming an important subject of discussion among researchers, policymakers and practitioners (OPAS, 2004). PC is a field of practice developed within the context of pharmaceutical assistance and includes three main axes: the social need for the rational use of medicines, the health care process and the medicine user as the main target (Bootman, Harrison, Cox, 1997). However, PC is not yet established as a routine practice among Brazilian pharmacists (Castro, Correr, 2007), even though PC is included in Brazilian law (Brasil, 2009).

In the field of scientific research, the scientific production is of substantial importance as it is an essential source of public knowledge. In fact, research can be viewed as only existing when published or when it is presented to the scientific community. Hence, scientific journals play a key role in spreading the knowledge gained through scientific research (Curty, Boccato, 2005; Araújo, Ueta, Freitas, 2005).

Bibliometric studies have been used to evaluate the existing scientific knowledge in different areas of study. The objective of bibliometrics is to ascertain the scientific and technical activity or to quantify the publications focused on the development of more reliable indicators (Filippo, Fernandez, 2002).

Therefore, bibliometric analysis has proven to be a useful tool for gathering information about the scientific activity in a given field or area of research (Iglesias, Rodríguez, Pérez, 2007; Coleman, Schlesselmann, White, 2007; Roughead, Semple, Vitry, 2006; Sokar-Todd, Einarson, 2003; Mayoral, Fernández, Rubio, 2005; Zarate, 1996; Witzel, 2009; Silva, 2009; Oshiro, 2008). For example, Coleman et al. (2007) used bibliometric analysis to prove that faculty members focusing on pharmacy practice in the Midwest region of the USA have a more relevant contribution to the biomedical literature than any other faculty in that country. The results of this study demonstrated the importance of the contributions of pharmacy schools to the literature (Coleman et al., 2007). Iglesias, Rodríguez,
Pérez (2007) assessed the scientific activity in Spain's pharmacist community and observed an increase in the number articles published from 2000-2005. This increase was attributed to the appearance of specialised journals (Iglesias, Rodríguez, Pérez, 2007).

Given the situation described above, it is important to examine the publications on PC and identify quantitative and qualitative parameters to objectively evaluate the knowledge.

To this end, the aim of the present study was to evaluate the quality and quantity of the scientific production regarding $\mathrm{PC}$ in Brazil and to subsequently compare it with those of two countries that have historically exerted substantial influence on this subject, the USA and Spain.

\section{MATERIALS AND METHODS}

This study included a search of the publications in scientific databases as a way to estimate the scientific production in the field of $\mathrm{PC}$.

\section{Inclusion criteria}

The estimation of the amount of scientific production about PC was based on the selection of articles published in indexed scientific journals in the following databases: Web of Science, Scopus, Medline, Lilacs and SciELO.

The inclusion criteria used are listed below:

a) Publications between 1990 and 2009;

b) Key words used: pharmaceutical care, atención farmacêutica and atenção farmacêutica (in quotation marks to avoid articles not related to PC). When searching for papers from a given country, the above-mentioned descriptors were added to the country name in English, Spanish or Portuguese;

c) The following selected countries: USA, Spain and Brazil. In this search, the limits adopted in (b) were not used, so that the articles that included the country name in the researchers' affiliations were also recovered;

d) In the Scopus database, the search was limited to the following sub-areas: "pharmacology, toxicology and pharmacy", "medicine" and "health professions".

\section{Exclusion criteria}

The results obtained from the searches of the databases were carefully analysed, and scientific studies with the following characteristics were excluded:

a) Not in the format of a scientific paper (i.e., books, dissertations, abstracts); 
b) Repeated in different searched databases (when repeated, each article was counted only once);

c) Not aligning with the PC topic area, as determined from the title or abstract.

The type of PC approach described in the article was not considered.

\section{Parameters analysed}

After gathering the global literature for this study, the articles were analysed as a unit and by selected countries as described below:

a) Number of papers, publication language and year of publication;

b) The quality of the publication according to the journal's impact factor and the stratum of the journal (see below);

c) Based on the number of papers, the impact factor and the relative value assigned to the journal (see below), a score of quality (SQ) was calculated to establish a parameter of comparison between the countries and the overall scientific production.

\section{Qualitative analysis of the scientific production}

\section{Impact factor and stratification of journals}

The production of scientific publications in the pharmacy field is evaluated every three years by a Brazilian institution, named the Coordenação de Aperfeiçoamento de Pessoal de Nível Superior (CAPES), which coordinates the improvement of higher education personnel. This institution is a government agency belonging to the Education Cabinet, which is responsible for the evaluation of the Stricto Sensu Post-graduation programs in Brazil. To classify the scientific journals, the CAPES foundation stratifies the articles into eight levels. The main stratification criterion is the indexing of the journal in the Institute for Scientific Information (ISI), Web of Science (Tomson Institute) and Scopus (SCImago Research Group, Elsevier $\mathrm{BV}$ ) databases, with the evaluation of the impact factor, or the indexing in the MEDLINE, LILACS, International Pharmaceutical Abstracts and SciELO databases, without evaluation of the impact factor. The journals included in this study were classified using the CAPES system with slight modifications (Table I).

The field of pharmacy coordination from CAPES considers two types of impact factors: the Journal Citation Reports (JCR), from the ISI base ( $\mathrm{j}$-index); and the impact factor from the SCImago / Elsevier base (h-index) (Ministério da Educação, 2009).
TABLE I - Criteria for stratification according to the $\mathrm{j}$ or $\mathrm{h}$ impact factors. Source: CAPES (2009)

\begin{tabular}{ll}
\hline Strata & Impact Factor $(\mathrm{j}$ or $\mathrm{h})$ \\
\hline A1 & $\mathrm{j} \geq 3.0$ \\
A2 & $3.0>\mathrm{j} \geq 2.3$ \\
B1 & $2.3>\mathrm{j} \geq 1.6$ \\
B2 & $1.6>\mathrm{j} \geq 0.8$ \\
B3 & $\mathrm{j}<0.8$ or $\mathrm{h}=5$ \\
B4 & $\mathrm{h}<5$ \\
B5 & Indexed in SciELO, MEDLINE, International \\
& Pharmaceutical Abstracts and LILACS, but not \\
& indexed in the Institute for Scientific Information \\
& (ISI), Web of Science (Thomson Institute) or Scopus \\
& (SCImago Research Group, Elsevier BV) \\
C & Not indexed in the databases listed in the B5 stratum \\
\hline
\end{tabular}

The quality of the scientific production was based on the frequency of publication in the different strata and on the average of the two types of impact factors analysed.

For purposes of comparison, the simple relative frequencies of the strata were grouped as follows: a) high qualification stratum (HQ): $\mathrm{A} 1+\mathrm{A} 2+\mathrm{B} 1+\mathrm{B} 2$; $\mathrm{b}$ ) intermediate qualification stratum (IQ): $\mathrm{B} 3$ and c) low qualification stratum (LQ): B4 + B5.

\section{Score of quality}

The SQ of the publications was applied as described by Oliveira et al. (2003), with modifications. A SQ was calculated for each journal to qualify the scientific journals in which PC publications were found. The formula used to calculate the score of quality is as follows: $S Q=\sum$ f.w.if; $\mathrm{SQ}=$ score of quality; $\mathrm{f}=$ frequency of article from $\mathrm{PC}$ field in each journal; $\mathrm{w}=$ relative value of the cited references; and if = impact factor.

The relative value assignment was based on the strata classification of the journals made by CAPES (Ministério da Educação, 2009) as follows: A1, relative value 10 ; A2, 8.5; B1, 7; B2, 5; B3, 3; B4, 1.5; B5, 0.5. The stratum $\mathrm{C}$ was excluded.

The impact factor used for the SQ calculation was the j-index. When the publication had only the h-index, it was converted to the $\mathrm{j}$-index according to the following criteria: a) h-index less than 5 was converted to $j$-index of $0.1, b) h$-index between 5 and 10 was converted to $j$-index of 0.25, c) h-index between 11 and 20 was converted to $\mathrm{j}$-index of 0.5 and d) h-index between 21 and 40 was converted to $\mathrm{j}$-index of 0.75 .

To ensure a nonzero score, the $\mathrm{j}$-index value of 0.01 was assigned for journals classified as B5 (without evalu- 
ation of the impact factor but indexed in the databases considered).

\section{Statistical analysis}

The data obtained in the survey were compiled in a spread sheet developed using Microsoft Excel software, Office version 2007. The compiled data were analysed using the Statistical Package Social Science program, version 11.5 (SPSS 11.5). Simple relative frequencies were calculated for qualitative variables within each group. For quantitative variables, one-way analysis of variance (ANOVA) and the Fisher post-hoc test were performed and the significance level was set at $5 \%$. These quantitative data were expressed as the mean and the standard error of the mean (S.E.M.).

\section{RESULTS}

A total number of 3,459 papers met the inclusion criteria and after applying the exclusion criteria, 194 articles were excluded. Three thousand two hundred and sixty five papers published about PC in 544 journals between 1990 and 2009 were analysed (Figure 1). As depicted in Figure 1, the publication of papers in the PC field has increased steadily from 1990 to 2009. This pattern is observed in Spain and Brazil, but the publication rates in the USA stabilised after 2000. The dominant language of the publications was English, representing $74.8 \%$ of the publications considered for analysis, followed by Spanish (6.5\%) and German (5.6\%) (Figure 2). When each country was considered separately, however, the mother language of each country was the most common language used in that country's publications, i.e., English for the USA (98\%), Spanish for Spain (74.6\%) and Portuguese for Brazil (54\%).

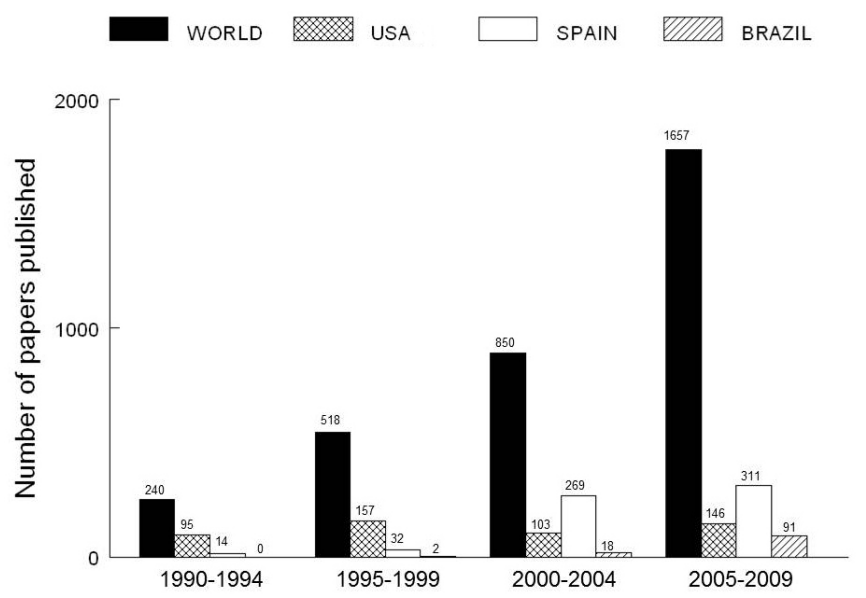

FIGURE 1 - Evolution of general scientific production and the production of each country in five-year intervals.

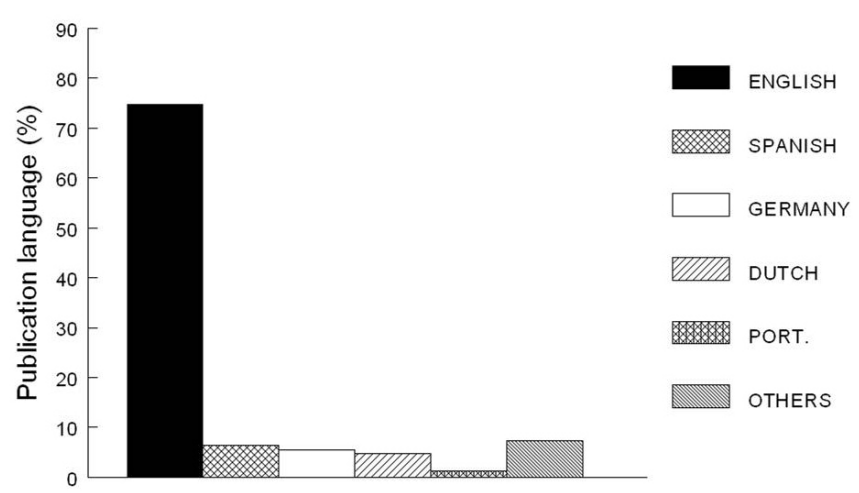

FIGURE 2 - Language frequencies in the general global production (WORLD) of published articles retrieved from PUBMED (Medline).

The USA presented the highest value for the h-index [40.5(3), $\mathrm{p}<0.01]$ followed by WORLD [29.8(2)], Spain [29.9(4)] and Brazil [23.2(4)]. The impact factor analysed according to the J.C.R. (j-index) shows that the average value for Brazil [2.05(0.2), $<<0.01]$ was lower than those of the other two selected countries [USA: 3.28(0.4), Spain: $2.50(0.3)]$ and that of the WORLD production [2.84(0.3)]. No substantial difference was observed among the WORLD, Spanish and USA production levels.

The frequency of the scientific production in the USA was higher in the high qualification stratum (HQ) and lower in the low qualification stratum (LQ) in relation to the frequencies of the WORLD production and the production of the other countries (Table II). The Spanish production frequency was second to the WORLD production frequency, and the Brazilian production frequency was the lowest in the HQ stratum among all analysed countries.

TABLE II - Frequency of scientific production by qualification stratum. High qualification stratum (HQ): A1 + A2 + B1 + $\mathrm{B} 2$; intermediate qualification stratum (IQ): $\mathrm{B} 3$; and low qualification stratum (LQ): B4 + B5

\begin{tabular}{lccc}
\hline & $\% \mathrm{HQ}(\mathrm{n})$ & \%IQ $(\mathrm{n})$ & \%LQ $(\mathrm{n})$ \\
\hline General & $30.5(166)$ & $30.5(166)$ & $39.0(212)$ \\
USA & $43.3(73)$ & $31.4(53)$ & $25.4(43)$ \\
Spain & $34.4(29)$ & $29.8(25)$ & $35.8(30)$ \\
Brazil & $23.5(11)$ & $38.3(18)$ & $38.3(18)$ \\
\hline
\end{tabular}

The highest SQ were assigned to the publications of the world [27.4(5)] and of the USA [29.5(7)]. The Spanish production SQ [15.3(3), $\mathrm{p}<0.01$ ] was lower than the world and U.S.A production scores, while the Brazilian production score [7.95(2), $\mathrm{p}<0.01]$ was the lowest.

The journal with the highest SQ was the Journal of 
the American Medical Association (JAMA) $(\mathrm{SQ}=1,585)$, in which five articles meeting the selection criteria were published. This journal has the maximum relative value and a J.C.R. of 31.7. The journal with the highest number of papers published in the PC field was the Pharmaceutical Journal, with 352 articles. Table III presents the top 20 journals based on their SQ, and Table IV presents the top 20 journals based on the number of articles published.

TABLE III - Top 20 journals based on the Score of Quality

\begin{tabular}{lc}
\hline Journal name & $\begin{array}{c}\text { Score of Quality } \\
\text { (SQ) }\end{array}$ \\
\hline Journal of the American Medical & $1,585.0$ \\
Association (JAMA) & $1,497.7$ \\
The Annals of Pharmacotherapy & 945.1 \\
Pharmacotherapy & 839.2 \\
American Journal of Health-System & \\
Pharmacy & 705.7 \\
Pharmacoepidemiology and Drug safety & 604.5 \\
Pharmacy World \& Science & 528.0 \\
Pharmaceutical Journal & 350.0 \\
Annals of Internal Medicine & 306.4 \\
Clinical Therapeutics & 286.9 \\
Nature Reviews Drug Discovery & 273.3 \\
Archives of Internal Medicine & 256.5 \\
British Medical Journal & 218.9 \\
British Journal of Clinical Pharmacology & 196.6 \\
Journal of Clinical Pharmacy and & \\
Therapeutics & 153.1 \\
American Journal of Medicine & 152.2 \\
Journal of the American Geriatrics Society & 132.0 \\
Lancet Oncology & 131.9 \\
Current Pharmaceutical Design & 124.3 \\
Patient Education and Counseling & 115.6 \\
Journal of General Internal Medicine &
\end{tabular}

\section{DISCUSSION}

The present study shows an increase in the number of articles in the PC field published in the period analysed. This finding indicates that this field of knowledge has been growing since 1990. An evaluation of the scientific literature on Pharmaceutical Care conducted by Silva (2009) from 1968 to 2008 also showed that the number of articles about PC has increased since 1990. The year 1990 was chosen as the first year of analysis because in this year, PC practice became a subject of global interest, which was
TABLE IV - Top 20 journals based on the number of papers published in the Pharmaceutical Care field

\begin{tabular}{lc}
\hline Journal name & $\begin{array}{c}\text { Number of } \\
\text { papers }\end{array}$ \\
\hline Pharmaceutical Journal & 352 \\
Pharmaceutisch Weekblad & 153 \\
Pharmaceutical Care España & 151 \\
Journal of the American Pharmaceutical & 110 \\
Association & \\
Pharmacy World \& Science & 85 \\
Pharmaceutical Care and Research & 79 \\
The Annals of Pharmacotherapy & 78 \\
International Journal of Pharmacy Practice & 75 \\
American Journal of Health-System Pharmacy & 68 \\
Farmacia Hospitalaria & 60 \\
Pharmacy Times & 58 \\
Atención Farmacéutica & 54 \\
American Journal of Hospital Pharmacy & 51 \\
U S Pharmacist & 49 \\
Pharmazeutische Industrie & 46 \\
Pharmacotherapy & 44 \\
Pharmazeutische Zeitung & 43 \\
Deutsche Apotheker Zeitung & 43 \\
Pharmacy Practice & 40 \\
American Pharmacy & 37 \\
\hline
\end{tabular}

the result of the publication of the classic paper by Hepler and Strand (Hepler, Strand, 1990). The data were limited to peer-reviewed papers, which represent the prevailing method of disseminating scientific knowledge (Narvai, Almeida, 1998). Despite these limitations, the articles selected for analysis represent an important opportunity to track the trends in research in the field of PC (Narvai, Almeida, 1998).

The quality of the journals retrieved was evaluated using the stratification levels recommended by the Pharmacy area of CAPES (Ministério da Educação, 2009), the impact factor and the SQ. The stratification of the journals by CAPES is based on the quality criteria described in the methods section, and the publications in the higher strata, together with the number of articles published, represent the productivity indicators used to evaluate research in all fields of knowledge. For this reason, the relative values assigned to journals by the pharmacy area from CAPES were used to calculate the SQ. This methodology also justifies the exclusion of stratum C of the CAPES classification from consideration in this study, because stratum 
$\mathrm{C}$ includes articles indexed in databases other than those included in the inclusion criteria and also because it describes a relative value of "zero" (Ministério da Educação, 2009).

The scientific production of the three countries analysed followed different patterns of evolution. These differences should reflect the evolution of the PC field in these countries. In the first decade considered (1990-1999), the production in the USA was markedly greater than that in other countries. The American scientific production was most likely stimulated by the hallmark American study of Hepler and Strand (1990), from which the term Pharmaceutical Care originates. Therefore, the discussion of $\mathrm{PC}$ in the USA would benefit from an analysis that begins before 1990. In the second decade considered (2000-2009), the number of articles produced in the USA remained stable. This change may be attributable to an increase in the quality, rather than the quantity, of the articles published in the USA during this time, as shown by a higher frequency in the HQ stratum and a lower frequency in the LQ stratum compared to other countries.

Spain showed incremental increases in its frequency of publication from 1990 to 2009, with the highest frequency occurring between 2000 and 2004. The growth in this particular period could possibly be explained by the origin of the PC field in that country, which was marked by the introduction of Dáder's method of Pharmaceutical Care that was officially released in 2000 (Faus-Dáder, 2000), the publication of the Consensus of Pharmaceutical Care by the Spanish Cabinet of Health in 2001 (España, 2001) and the Second Consensus of Granada on Drug Related Problems in 2002 (Panel de Consenso Ad Hoc, 2002). The Spanish translation of the classic work of Hepler and Strand (1999) may also have contributed to increasing the dissemination of knowledge about PC in Spain, which led to the increase in the frequency of scientific production in this field.

Brazilian production increased from 1990 to 2009 , although the overall number of publications is lower than those of the USA and Spain. In the first analysed decade, only two articles could be recovered that met the inclusion criteria. In 2002, recommendations from the Brazilian Consensus on Pharmaceutical Care stimulated the practice of PC in Brazil, which is likely the reason for the increase of the production in Brazil in the second decade considered. Recently, the National Health Surveillance Agency of Brazil (Agência Nacional de Vigilância Sanitária - ANVISA) has instituted a law concerning PC practice in pharmacies (Brasil, 2009).

Some studies about Brazilian scientific production on $\mathrm{PC}$ have shown a remarkable trend in the production in the PC field since 2000 (Witzel, 2009; Oshiro, Castro, 2008; Pereira, Freitas, 2008). However, those studies include other types of scientific production, such as unindexed articles, abstracts, and books. The present study focused on articles published in qualified journals that are at least indexed in the databases listed by CAPES (Ministério da Educação, 2009).

It is worth mentioning that the recommendations of the Brazilian Consensus on Pharmaceutical Care (Consenso Brasileiro de Atenção Farmacêutica - Proposta, 2002) have most likely been an important instrument for boosting PC in Brazil. Brazilian production has increased 20 -fold between 2000 , when approximately 4 articles were retrieved, and 2009. Witzel (2009) also retrieved only a few articles about PC in indexed journals before 2002. An increase in the Brazilian production of publications on PC was also observed beginning in 2006 (Witzel, 2009; Oshiro, Castro, 2008; Ferreira, 2008).

Ferreira (2008) still highlights that a significant number of articles in the area of PC have been submitted for publication in the Brazilian Journal of Pharmaceutical Sciences. This fact reflects the structuring of this area in this country, as well as the trends in education based on the new curriculum guidelines, in which PC has been inserted as a compulsory subject in the curricula of most pharmacy courses.

The dominant language of publications was English. A similar result was also observed by Silva (2009). English seems to be the language that provides the highest visibility for publications (Silva, 2009).

When examining individual countries, the publications are principally in the mother language of that country, i.e., English for the USA (98\%), Spanish for Spain (74.6\%) and Portuguese for Brazil (54\%). This trend can put Brazilian scientific production at a disadvantage by reducing its impact in the international community, as Portuguese corresponded to only $1.3 \%$ of the total publications. However, the frequency of English in the Brazilian production was relatively high (49\%), which may reflect the tendency of the Brazilian researchers to use English to improve the visibility of their publications. This trend can be clearly observed due to the fact that many of the journals indexed in the SciELO database (Latin America) are either completely in English or are in English and another language, with the intention of increasing the visibility of these publications in the international community (Silva, 2009).

Brazilian participation in HQ production is less frequent than that of other countries. This finding could be a result of the journals in which Brazil publishes its studies, which have a lower average impact factor than the journals selected by the other countries. 
The difference in the results between the $h$ and $j$ indexes may result from the fact that much of the Brazilian production is in the B3 stratum, which in many cases presents an h-index but not a j-index evaluation. This may have led to an overestimation of the Brazilian production impact factor.

The scores of quality allow for equal comparision and still consider the frequency of publication in a certain journal and the relative value assigned by the Pharmacy area of CAPES (Ministério da Educação, 2009). This calculation was performed to better evaluate the quality of journals in the area of PC and, hence, the WORLD production and the production of selected countries.

The score of quality indicates that the USA has the best quality of publications, although the USA is below Spain in terms of quantity. Although the USA production did not increase in terms of quantity in the last decade, it is likely that there is a trend towards quality over quantity in the publications in this field. In fact, three of the five relevant articles published in JAMA and approximately half of those published in The Annals of Pharmacotherapy came from the USA.

It can also be observed that the number of articles seems to be the main factor influencing the difference in SQ between Spain and Brazil, given that the JCR values of the two countries, although significantly different, are still very close.

\section{CONCLUSION}

The results of this study indicate that the scientific production in the area of Pharmaceutical Care around the world has been steadily evolving since 1990 although it follows different patterns of evolution in terms of quality, quantity and time. The American production is of the highest quality, whereas Spain published the greatest number of papers among the three analysed countries. Brazil's evolution showed impressive development over the last five years of the analysed time period. In comparison to the other countries, the Brazilian production on PC is low and an increase in the quantity and quality of the publications in Brazil should be encouraged.

\section{LIMITATIONS OF THE STUDY}

We calculated an SQ with the aim to standardise the evaluation of the quality of the journals. However, our study did not present a qualitative analysis of the objective, methods and results of each retrieved article, and these components are not reflected in the SQ formula. Therefore, it is possible that a well-designed study has been published in a journal with a low SQ and vice-versa, and readers should therefore not always consider a journal with no impact factor or a low SQ as a low quality scientific journal.

\section{ACKNOWLEDGEMENTS}

This work was supported with funds from Rede Brasileira de Assistência Farmacêutica e Vigilância de Medicamentos do Instituto Nacional de Ciência e Tecnologia para Inovação Farmacêutica (REBRAFVIME / INCT_if) and Conselho Nacional de Desenvolvimento Científico e Tecnológico (CNPq).

\section{REFERENCES}

ARAÚJO, A.L.A.; UETA, J.M.; FREITAS, O. Assistência farmacêutica como um modelo tecnológico em atenção primária à saúde. Rev. Ciênc. Farm. Básica Apl., v.26, p.87-92, 2005.

BOOTMAN, J.L.; HARRISON, D.L.; COX, E. The health care cost of drug-related morbidity and mortality in nursing facilities. Arch. Intern. Med., v.157, p.2089-2096, 1997.

BRASIL. Agência Nacional de Vigilância Sanitária. Resolução RDC n 44, de 17 de Agosto de 2009. Dispõe sobre as Boas Práticas Farmacêuticas para o controle sanitário do funcionamento, da dispensação e da comercialização de produtos e da prestação de serviços farmacêuticos em farmácias e drogarias. Diário Oficial da União, n. 134, 14 Jul 2009, seção 1, p.86.

COLEMAN, C.I.; SCHLESSELMANN, L.; WHITE, C.M. Journal publications by pharmacy practice faculty evaluated by institution and region of the United States (2001-2003). Pharm. Pract., v.5, p.151-156, 2007.

CONSENSO BRASILEIRO DEATENÇÃO FARMACÊUTICA - Proposta. Atenção Farmacêutica no Brasil: "Trilhando caminhos". Brasília (DF), 2002. 24p.

CURTY, M.G.; BOCCATO, V.R.C. O artigo científico como forma de comunicação do conhecimento na área de ciências da informação. Perspect. Ciênc. Inf., v.10, p.94-107, 2005.

CASTRO, M.S.; CORRER, C.J. Pharmaceutical care in community pharmacies: practice and research in Brazil. Ann. Pharmacother., v.41, p.1486-1493, 2007.

ESPAÑA. Ministerio de Sanidad y Consumo. Consenso sobre atención farmacêutica. Madrid, 2001. 
FAUS-DÁDER, M.J. El programa Dáder. Pharm. Care Esp., v.1, p.73-74, 2000.

FAUS-DÁDER, M.J.; MARTÍNEZ, F.M. La Atención Farmacéutica en farmacia comunitaria: evolución de conceptos, necesidades de formatión, modalidades y estrategias para su puesta en marcha. Pharm. Care Esp., v.1, p.2-61, 1999.

FERREIRA, E.I. Editorial [Editorial]. Rev. Bras. Ciênc. Farm., v.44, p.4, 2008.

FILIPPO, D.; FERNANDEZ, M.T. Bibliometría: importancia de los indicadores bibliométricos. In: ALBORNOZ, M. (Eds.) El estado de la ciencia: principales indicadores de ciencia y tecnología iberoamericanos/interamericanos. Buenos Aires: Artes Gráfica Integradas, 2002.

HEPLER, C.D.; GRAINGER-ROUSSEAU, T.J. Pharmaceutical care versus traditional drug treatment. Is there a difference? Drugs, v.49, p.1-10, 1995.

HEPLER, C.D.; STRAND, L.M. Opportunities and responsibilities in pharmaceutical care. Am. J. Hosp. Pharm., v.47, p.533-543, 1990.

HEPLER, C.D.; STRAND, L.M. Oportunidades y responsabilidades en la atención farmacéutica. Pharm. Care Esp., v.1, p.35-47, 1999.

HUDGENS, J.R.; CHIRICO, M.J. A course introducing the principles of pharmaceutical care. Am. J. Pharm. Educ., v.74, p.131, 2010.

IGLESIAS, J.C.A.; RODRÍGUEZ, N.F.A.; PÉREZ, J.A.F. Community pharmacy-based research in Spain (19952005): A bibliometric study. Pharm. Pract., v.5, p.21-30, 2007.

MARTÍNEZ, A.M. La profesión farmacéutica:una panorámica general de su práctica y enseñanza en Cuba. Pharm. Care Esp., v.1, p.363-368, 1999.

MINISTÉRIO DA EDUCAÇÃO DO BRASIL - Coordenação de Aperfeiçoamento de Pessoal de Nível Superior (CAPES). Documento de área 2009. Available at: <http://www.capes. gov.br/images/stories/download/avaliacao/FAR23out09. pdf $>$. Accessed on: Mach 2010.
NARVAI, P.C.; ALMEIDA, E.S. O sistema de saúde e as políticas de saúde na produção científica odontológica brasileira no período de 1986-1993. Cad. Saúde Publica, v.14, p.513-521, 1998.

OLATUNDE, S.; BOON, H.; HIRSCHKORN, K.; WELSH, S.; BAJCAR, J. Roles and responsibilities of pharmacists with respect to natural health products: key informant interviews. Res. Social. Adm. Pharm., v.6, p.63-69, 2010.

OLIVEIRA, F.Q.; JUNQUEIRA, R.G.; STEHMANN, J.R.; BRANDÃO, M.G.L. Potencial das plantas medicinais como fonte de novos antimaláricos: species indicadas na bibliografia etnomédica brasileira. Rev. Bras. Plantas Med., v.5, n.2, p.23-31, 2003.

ORGANIZAÇÃO PAN-AMERICANA DA SAÚDE OPAS; Conselho Federal de Farmácia - CFF. O papel do farmacêutico no sistema de atenção à saúde. Brasília (DF), 2004, n.p.

OSHIRO, M.L.; CASTRO, L.L.C. Atenção farmacêutica: revisão bibliográfica da produção brasileira de 1999 a 2005. In: STORPIRTIS, S.; MORI, A.L.P.M; YOCHIY, A.; RIBEIRO, E.; PORTA, V. (Eds.). Farmácia clínica e atenção farmacêutica. 1ed. Rio de Janeiro: Guanabara Googan, 2008. p.411-429.

PANEL DE CONSENSO AD HOC (ESPAÑA). Segundo Consenso de Granada sobre problemas relacionados com medicamentos. Ars. Pharmaceutica, v.43, p.175-184, 2002.

PENNA, R.P. Pharmaceutical care: pharmacy's mission for the 1990s. Am. J. Hosp. Pharm., v.47, p.543-549, 1990.

PEREIRA, L.R.L.; FREITAS, O. A evolução da atenção farmacêutica e a perspectiva para o Brasil. Rer. Bras. Ciênc. Farm., v.44, p.601-12, 2008.

MAYORAL, J.F.R.; FERNÁNDEZ, J.L.; RUBIO, F.J.L. Estado actual de la investigación en atención farmacéutica. Farm. Hosp., v.29, p.335-342, 2005.

ROUGHEAD, L.; SEMPLE, S.; VITRY, A. The value of pharmacist professional services in the community setting: a systematic review of the literature 1990-2002. Available at: http://beta.guild.org.au/research/funded_projects.asp. Accessed on: 10 june 2006. 
SILVA, W.B. A emergência da atenção farmacêutica: um olhar epistemológico e contribuições para o seu ensino. Florianópolis, 2009. 305p. [Thesis of PhD degree. Federal University of Santa Catarina].

SOKAR-TODD, H.B.; EINARSON, T.R. Community pharmacy practice research: a systematic review of the past 32 years. Can. Pharm. J., v.136, p.26-38, 2003.
WITZEL, M.D.R.F. Produção científica brasileira na área de atenção farmacêutica entre 1990 e 2007. São Paulo, 2009. 93p. [Dissertion of Master degree. Faculty of Public Health. University of São Paulo].

ZARATE, J.D.A.O. La investigación en farmacia comunitaria. Trabajos publicados en Atención Primaria y Farmacia Clínica (1992-1995). Farm. Clin., v.13, p.118-122, 1996.

Received for publication on $18^{\text {th }}$ March 2012 Accessepted for publication $06^{\text {th }}$ November 2012 
